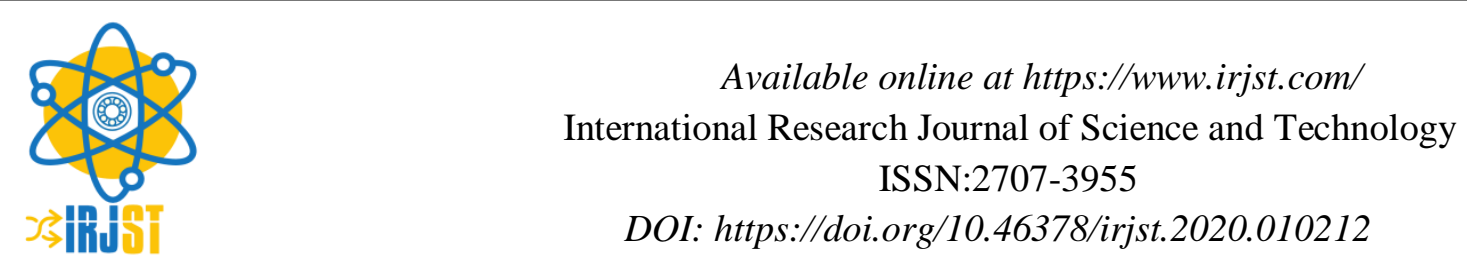

\title{
Appraising the Forensic Services in Crime Investigation: A Study on Police Officers from Gamo Zone in SNNPR, Ethiopia
}

\author{
Shunmuga Sundaram $\mathbf{G}^{1} *$, Suresh Kumar $\mathbf{R ~}^{2 *}$, Taye Cherga ${ }^{3}$ and Dersolegn Yeneabat ${ }^{4}$ \\ ${ }^{1}$ Assistant Professor, School of Law, Arba Minch University, Arba Minch. \\ ${ }^{2}$ Assistant Professor, Forensic Toxicology Division, Dept of Chemistry, Arba Minch University, Arba Minch. \\ ${ }^{3}$ Assistant Commissioner of Police/Deputy commissioner (Crime Prevention-SNNPR) and Post Graduate, MA \\ Human Rights and security Studies. School of Law, Arba Minch University, ArbaMinch \\ ${ }^{4}$ Dean, School of Law, Arba Minch University, Arba Minch.
}

\begin{tabular}{lll}
\multicolumn{2}{l}{ Paper Status } & \\
Received & $:$ & February 2020 \\
Accepted & $:$ & March 2020 \\
Published $:$ & March 2020
\end{tabular}

Key Words

Evidence

Forensic

Intervention

Investigation

Police officers

\begin{abstract}
Criminal investigation is an art of uncovering the truth for the purpose of successful detection and prosecution. A successful and reliable investigation to stand for the justice requires a competent investigator and the use of technological aids from forensic and other scientific disciplines. This paper investigates the common perception among the police officers at different designation levels working in the Gamo region, SNNPR on the application of forensic services in crime investigation.

The major objectives of this study are to a) Identify the level of awareness on forensic service among the crime investigation officers and b) To identify the lacunae in implementation of forensic services in crime investigation process. The sample size of 70 police officers in all categories of Constable, SubInspector, Inspector, Deputy Commissioner in the Gama zonal region were included as respondents of the study. A purposive sampling method was adopted and structured questionnaire was used for the data collection. Statistical interpolation of the results was done using SPSS software. This study identified the lack of awareness among the police officers working in lower hierarchy level $(<50 \%)$ on various forensic services, specialized forensic divisions, and application of forensic approaches during crime investigation. A positive correlation was observed with respect to the designation of officers and the lack of awareness among the police officers. Majority $(<65 \%)$ of the police officers were not aware of the existence of fingerprinting division in the country. There exists a poor communication between key actors in the criminal justice system and financial resources not directed at the front end of the forensic process. The outcomes of this study would facilitate the identification of the lacunae in implementation of forensic services in the crime investigation process. This study emphasizes the need for immediate attention on managing the forensic illiteracy among police officers, mainly on the field such as fingerprint analysis, criminal investigation methods and cybercrime. It is the need of hour to promote the establishment of forensic wing at Gamo zonal level law enforcement.
\end{abstract}

Copyright (c) 2020: Shunmuga Sundaram G, Suresh Kumar R S, Taye Cherga and Dersolegn Yeneabat. This is an open access distribution, and reproduction in any medium, provided Access article distributed under the Creative Commons Attribution License the original work is properly cited License, which permits unrestricted use.

Citation: Shunmuga Sundaram G, Suresh Kumar R S, Taye Cherga and Dersolegn Yeneabat. "Appraising the Forensic Services in Crime Investigation: A Study on Police Officers from Gamo Zone in SNNPR, Ethiopia". International Research Journal of Science and Technology, 1 (2), 155-161, 2020. 


\section{Introduction}

The wing of law enforcement and crime investigation agencies provide vital support to the criminal justice system to withstand the justice of a country [1]. Forensic services have become the indispensable part of the criminal investigation because they deliver timely and precise information at different stages of the criminal justice process. The ultimate objective of forensic science is to use the scientific and technological advancements to decipher the truth by means of prime interrogation and objective evidences that can help the criminal justice system to determine the guilt or innocence of an offender [2-4]. The forensic services are mostly used by the police officers to identify the suspects in the investigative phase of the criminal justice. The government attorneys and judges use them during the trial phase of the process. Assessing forensic services from the crime scene to the courtroom is complex and should include legal, structural and non-technical well as technical aspects. Therefore, it is quintessential that forensic services are provided by a highly qualified and impartial entity. Under the public sector, the agencies that provide forensic services are the governmental institutes coming under the auspice of ministry of justice, internal affairs and the ministry of health.

Certain forensic services can only be provided by the trained persons by using the police facilities to process crime scenes and perform primary forensic examinations (e.g., fingerprints) [5]. During crime investigation, the intervention of the crime scene investigators, who have received full-fledged forensic training, is needed and they have to quickly take over the work at the scene. However, in many situations, there is no prospect for the crime scene to be processed by crime scene investigators. In such case, the first responders (such as police officers) have to carry out some basic recovery procedures as well as the preservation and documentation activities. These situations typically occur if the crime scene is in a remote location, lack of skilled personnel, lack of awareness among the investigating officers and the criminal justice system response is not adequate [6]. Therefore, it is exceedingly important for police officers (first responders) to be thoroughly acquainted on various aspects of the crime scene investigation starting from the preservation of the scene and its evidence, documentation and subsequent transport of evidence to the forensic laboratory.

*Corresponding Author: Shunmuga Sundaram G

Assistant Professor, School of Law, Arba Minch University,

Arba Minch.

Email : drshunmuga@gmail.com
At all the aforementioned levels of crime investigation it is essential for the police officer to have careful planning, organization and coordination of the work [7].

The interview of criminals by police officers also requires an adequate knowledge on crime investigation as well as understanding the forensic results. A prospective study carried out by Lisa and Ray, 2014 on the use of forensic evidence in the context of police interviews revealed that majority of police officers were not aware of the forensic information while interviewing the subjects [8]. Despite of the availability of large proportion of forensic evidence during the interviews, the majority of police interviewers have received no training about how to interpret or use such forensic information. The study highlights the importance of forensic knowledge to the first responders and basic training has to be imparted to all police officers working on Crime prevention.

\subsection{Statement of Problem}

In Ethiopia, Federal Police Commission (FPC) has a forensic division directorate in national level conducts criminal investigation by various specialized units and its coordinate all regional police commissions around country to engage detection, investigation, power to seizure, confiscate evidence and prosecution of criminal cases which enforces laws $[9,10]$. According to Federal police report 2003, in Ethiopia reveals that country has only one forensic laboratory to deal all the basic finger print analysis, blood analysis, document examination and other scientific related examinations by various experts in forensic investigation. Due to the shortage of laboratories to deal the scientific investigation leads more delay of overburden of case analysis, reduce the competency and performance by the single laboratories. In the other hand the training on forensic investigation of basic skill of collection and preservation of evidence from crime scenes to the police officers is big gap in the police routine work [11].

Even though the 11 police training college across in Ethiopia, it's not much reach to all the police personals to deal the criminal investigations with forensic approach. The police-public ratio is lacking to deal the criminal investigation in scientific way in Ethiopia and even country have laboratories but most of time complex cases dealt by aboard laboratories [12]. The purpose of this paper is to identify the bottlenecks in the use of forensic services in the criminal justice system by adopting a survey approach which examines the awareness among the different levels of police officers belonging to Gamo zone of SNNPR region, Ethiopia. The level of awareness from the collection 
and use of forensic evidence from crime scene to court was analysed. This paper uses in-depth analysis of qualitative data from the 70 respondents (police officers) to identify key risk factors that limit the use of forensic science at the crime scene.

\section{Methodology}

The sample size of 70 police officers in all categories of Constable, Sub- Inspector, Inspector, Deputy Commissioner in the Gama zonal region were included as respondents of the study. A purposive sampling method was adopted and structured questionnaire was used for the data collection. The Questionnaire was Blind peer reviewed and necessary corrections were made before survey. All the survey questions were given in Amharic and English language. Statistical interpolation of the results was done using SPSS software. Correlation among the different variables used in the study was analyzed by Pearson correlation coefficient method using the SPSS software.

\section{Results}

\subsection{Sample Profile}

The sample profile data is represented in the Table1. Majority of the respondents of this study were Males $(85.7 \%)$, educated up to school level $(65.7 \%)$. Female respondents accounted for $14.3 \%$ of the sample. Among the study respondents, $57.1 \%$ was identified to be married and $42.9 \%$ unmarried. More number of people were found to be in the designation of police Constable (42.9\%) whereas the other designations such as Assistant Inspector, Deputy Inspector, Commandant, Chief Inspector and Assistant Commissioner were found to be $22.9 \%, 14.3 \%, 14.3 \%$, $4.3 \%$ and $1.4 \%$ respectively. In terms of experience $31.4 \%$ of the police have 1 to 5 years of experience, $17.1 \%$ have 11 to 15 years of experience, $12.9 \%$ have 16 to 20 years of experience. Only $1.4 \%$ of the police officers were identified to have more than 30 years of work experience in the Gamo zone police jurisdiction.

\subsection{Participation of Police Officers in Crime Investigation}

In order to understand the participation of police personnel in the crime investigation, the primary respondent variables were divided into three groups (Yes, No and Don't Know) and their respective level of participation in different category of crimes (crime against person, crime against property, traffic accident and cybercrime were identified.

From the figure 1, it is evident that majority of the cases investigated by the police was the Hurt and Grievous category $(60 \%)$. The other crimes such as murder, attempt to murder, rape and attempt to rape have similar percentage $(55.7 \%)$ of investigation experience by the police officers.

\section{Crime Against Person}

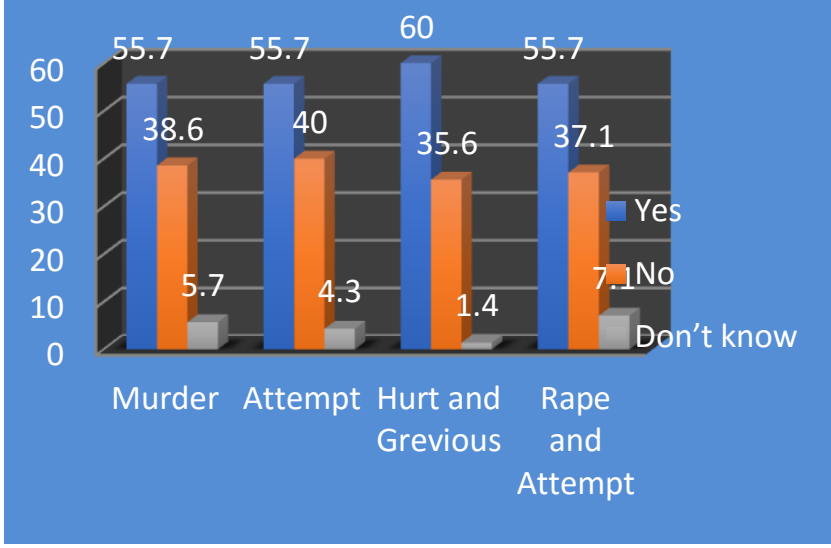

Figure 1. Participation of policers officers in various crime investigation

Table 1. Sample profile of the study respondents

\begin{tabular}{lll}
\hline Particulars & Number & Present \\
\hline Sex & 60 & 85.7 \\
Male & 10 & 14.3 \\
Female & & \\
\hline Education & 46 & 65.7 \\
School & 24 & 34.3 \\
Under Graduate & .0 & .0 \\
Post Graduate & & \\
Marital Status & 30 & 42.9 \\
Unmarried & 40 & 57.1 \\
Married & & \\
\hline Designation & 30 & 42.9 \\
Constable & 16 & 22.9 \\
Assistant Inspector & 10 & 14.3 \\
Deputy Inspector & 3 & 4.3 \\
Chief Inspector & 1 & 1.4 \\
Assistant Commissioner & 10 & 14.3 \\
Commandant & & \\
\hline Year Of Experience & & 31.4 \\
1 To 5 & 22 & 4.3 \\
6 To 10 & 3 & 17.1 \\
11 To 15 & 12 & 12.9 \\
16 To 20 & 9 & 8.6 \\
21 To 25 & 6 & 24.3 \\
26 To 30 & 17 & 1.4 \\
31 To 35 & 1 & \\
\hline & & \\
3 & & \\
\hline
\end{tabular}

3.3 Investigation knowledge on cases related to Crime against property

The figure 2 give details about the crime investigation knowledge and the experience of the police officers in specific category of crime against property. It is evident that $58.6 \%$ of police persons had experience in the investigation of 
theft related crime, $45.7 \%$ on robbery, $42.9 \%$ on dacoity and burglary and $44.3 \%$ on the cases related to the cheating.

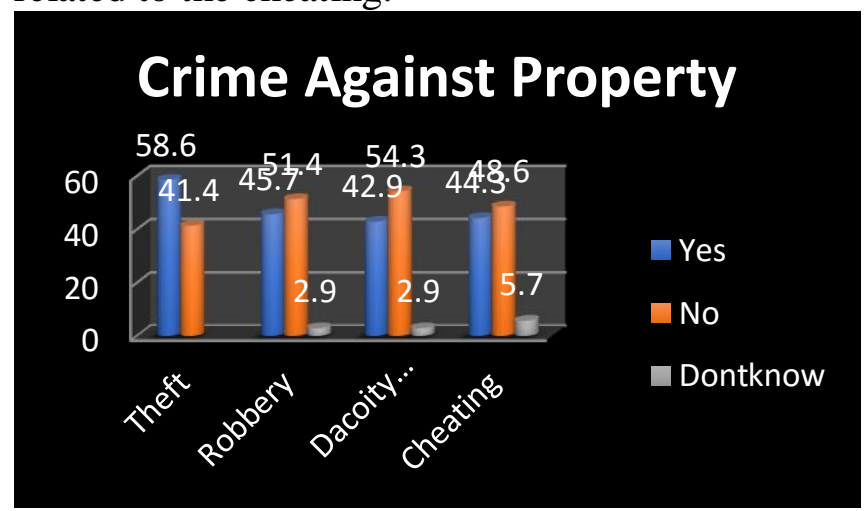

Figure 2 Investigation knowledge among officers on the cases related to crime against property.

\subsection{Investigation Knowledge on Cases Related to Road Accidents and Cyber Crime}

The graphs represented in the figure 3, reveals the investigation knowledge of the police personnel on the category of Road accidents and Cybercrime. Majority of the police $(72 \%)$ have neither participation nor investigation involvement in cases related to the road accidents. Similarly, $84 \%$ of police person in the Gamo zone was not found to have any have experience related to the Cybercrime.

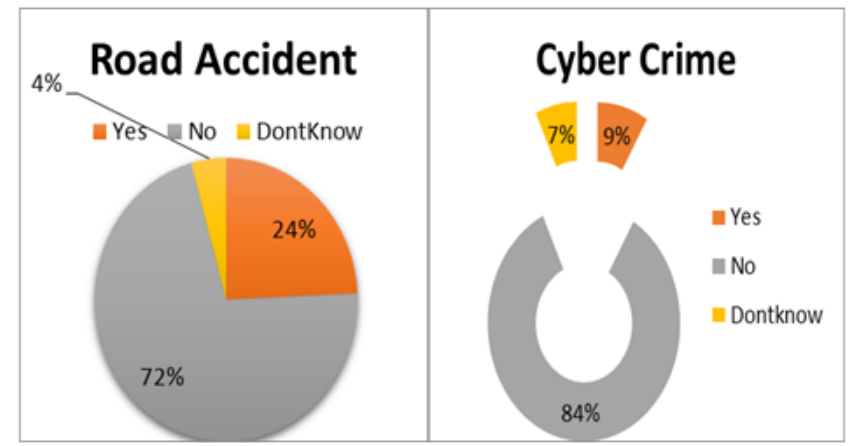

Figure 3. Police knowledge on the criminal cases related to Traffic accidents and Cyber crime

\subsection{Role of Police Officers in Crime Investigation}

The role of police officers in the crime investigation was assessed based on their involvement at various categories of crime investigation such as handling crime suspects and witness investigation, interrogation of the suspects and victims of crime, receiving complaints from victims and tactical approach or conceptual analysis of crime incidents respectively.

From the figure 4 , it is evident that $58.6 \%$ of police personnel were found to have equal participation in interrogation and handling complaints from crime victims as well as interrogating the suspects. Around $55.7 \%$ of the police officers were handling suspects and witness of crime and had conceptual understanding on the various approaches in crime investigation.

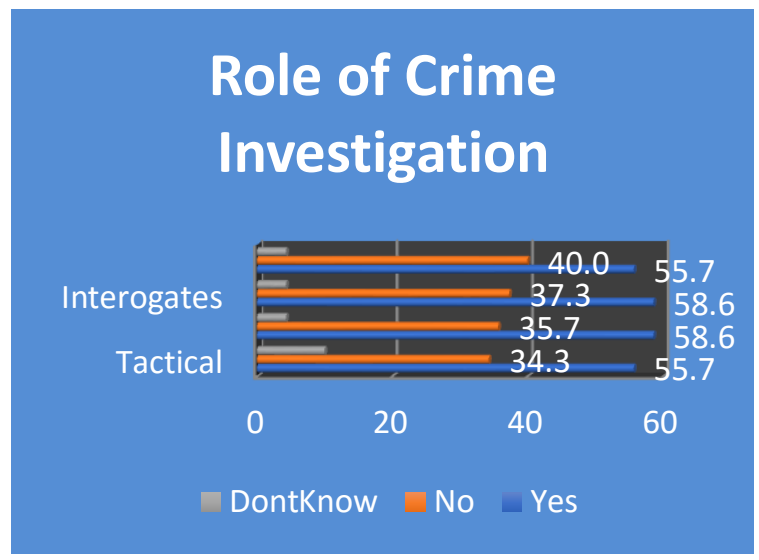

Figure 4. Role of police officers in crime investgation

\subsection{Technical knowledge on forensic interventions in crime investigation}

The survey results pertaining to the technical forensic knowledge among police officers on various approaches in crime scene handling such as evidence collection, preservation, examination of evidence, documentation and sketching the crime scene is represented in the figure 5. Majority (60\%) of study respondents had no experience in examination of evidence and $57.1 \%$ have no knowledge about preserving the evidence in the crime scene. The technical knowledge in documenting the crime scene, videotaping and sketching the crime scene was found to be $65.7 \%, 64.3 \%$ and $57.1 \%$ respectively. Among the study respondents, $4.3 \%$ of police officers have no knowledge on any of the forensic techniques related to crime scene investigation.

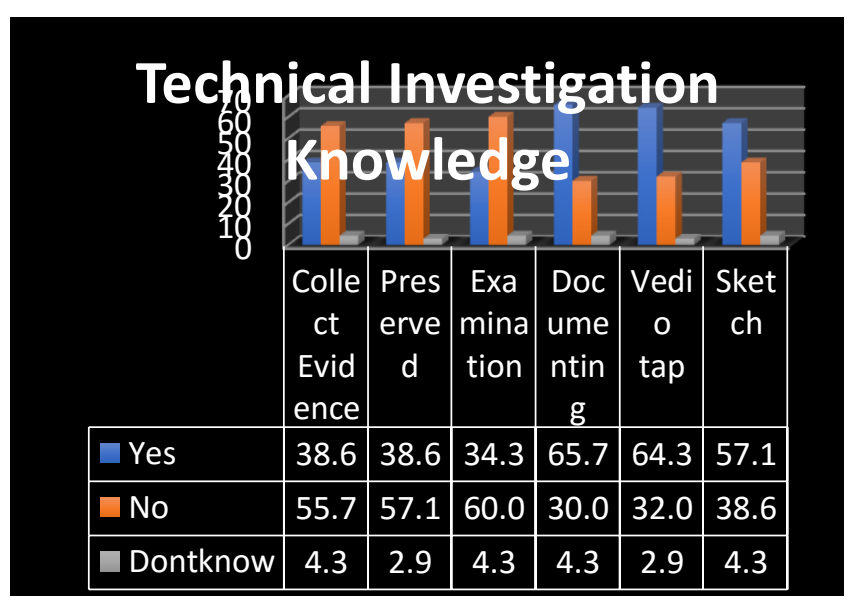

Figure 5. Technical knowledge of police officers related to forensic crime investigation techniques

The table 2 highlights the knowledge differences among the police officers working in the Gamo zone on various technical divisions of forensic department. 
Majority of the police officers $65.7 \%$ don't have any knowledge or experience related to blood pattern analysis, ballistics, questioned documents and serology. An alarming fact in this survey was that 64.3 $\%$ of the police officers were not aware of the existence of finger print division in the country.

Table 2. Knowledge of police officers on different disciplines of forensic science

\begin{tabular}{|c|c|c|c|c|}
\hline $\begin{array}{l}\text { Knowledge of } \\
\text { Division in } \\
\text { Forensic } \\
\text { Investigation }\end{array}$ & Yes & No & $\begin{array}{l}\text { Don't } \\
\text { know }\end{array}$ & $\begin{array}{l}\text { Total } \\
\%\end{array}$ \\
\hline $\begin{array}{l}\text { Impression/Finger } \\
\text { print Wing }\end{array}$ & 7.1 & 28.6 & 64.3 & 100 \\
\hline $\begin{array}{l}\text { Blood pattern } \\
\text { Analysis }\end{array}$ & 11.4 & 22.9 & 65.7 & 100 \\
\hline $\begin{array}{l}\text { Ballistics } \\
\text { /Firearms/Tool } \\
\text { marks }\end{array}$ & 11.4 & 22.9 & 65.7 & 100 \\
\hline $\begin{array}{l}\text { Questioned } \\
\text { Documents }\end{array}$ & 12.9 & 21.4 & 65.7 & 100 \\
\hline $\begin{array}{l}\text { Medico-legal } \\
\text { death } \\
\text { Investigation }\end{array}$ & 8.2 & 35.9 & 55.9 & 100 \\
\hline $\begin{array}{l}\text { Biology and } \\
\text { Serology }\end{array}$ & 5.7 & 28.6 & 65.7 & 100 \\
\hline $\begin{array}{l}\text { Fire/Arson } \\
\text { Analysis }\end{array}$ & 7.1 & 35.7 & 57.2 & 100 \\
\hline Toxicology & 4.3 & 40 & 55.7 & 100 \\
\hline $\begin{array}{l}\text { Cybercrime } \\
\text { Forensics }\end{array}$ & 5.8 & 37.1 & 57.1 & 100 \\
\hline
\end{tabular}

The table 3 shows the various barriers experienced by the police officers during crime investigation. $47.1 \%$ of police personnel were not allowed to apply forensic investigation methods and only $24.3 \%$ were allowed to apply in their crime investigation process. The prominent finding observed was that $45.7 \%$ of police officers were not given permission to conduct forensic investigation. $34.3 \%$ of the respondents encountered the lack of access to forensic services during their investigation. Another important finding was that around $42.9 \%$ of police officers reported on the insufficient availability of forensic infrastructure in the Gamo region.

\subsection{Correlation Analysis}

The inter-correlation matrix generated based on the Karl Pearson's correlation values, between all the continuous variables selected for the study are represented in the Figure 6. From the Correlation Matrix it can be seen that there is a strong positive correlation between Designation and Forensic application in Investigation $(\mathrm{r}=0.187 ; \mathrm{p} \leq 0.1$ level). This indicates that the hierarchal organization in the police system has a strong influence on the application of forensic services
Table 3. Professional challenges faced by the police officers during crime investigation

\begin{tabular}{|c|c|c|c|c|}
\hline $\begin{array}{l}\text { Barriers to Apply } \\
\text { forensic } \\
\text { Knowledge } \\
\text { /application } \\
\text { crime Investigation }\end{array}$ & Yes & No & $\begin{array}{l}\text { Don't } \\
\text { Know }\end{array}$ & $\begin{array}{l}\text { Total } \\
\%\end{array}$ \\
\hline $\begin{array}{l}\text { Allowed to apply } \\
\text { Forensic } \\
\text { investigation }\end{array}$ & 24.3 & 47.1 & 28.6 & 100 \\
\hline $\begin{array}{l}\text { Superior officer } \\
\text { allowed/Give } \\
\text { permission }\end{array}$ & 28.6 & 45.7 & 25.7 & 100.0 \\
\hline $\begin{array}{l}\text { Do you suffer any } \\
\text { forensic lack in } \\
\text { your investigation? }\end{array}$ & 34.3 & 42.8 & 22.9 & 100.0 \\
\hline $\begin{array}{l}\text { Do you have } \\
\text { accessible } \\
\text { coordination to the } \\
\text { forensic laborites? }\end{array}$ & 25.7 & 48.6 & 25.7 & 100.0 \\
\hline $\begin{array}{l}\text { Do you feel any } \\
\text { case acquittal for } \\
\text { insufficient of } \\
\text { forensic } \\
\text { availability in your } \\
\text { case? }\end{array}$ & 30.0 & 42.9 & 27.1 & 100.0 \\
\hline
\end{tabular}

\begin{tabular}{|c|c|c|c|c|c|c|}
\hline \multicolumn{7}{|c|}{ Correlations } \\
\hline & & $\begin{array}{l}\text { Forensic } \\
\text { Application in } \\
\text { Investigation }\end{array}$ & $\begin{array}{l}\text { Knowledge of } \\
\text { Forensic } \\
\text { Divisions }\end{array}$ & $\begin{array}{l}\text { Challenges } \\
\text { and } \\
\text { Importance } \\
\text { apply } \\
\text { Forensic } \\
\text { Investigation }\end{array}$ & Designation & $\begin{array}{l}\text { Year of } \\
\text { experience }\end{array}$ \\
\hline \multirow{3}{*}{$\begin{array}{l}\text { Forensic Application in } \\
\text { Investigation }\end{array}$} & Pearson Correlation & \multirow[t]{2}{*}{1} & $.264^{\circ}$ & .226 & -187 & -160 \\
\hline & Sig. (2-tailed) & & .027 & .060 & .120 & 185 \\
\hline & N & 70 & 70 & 70 & 70 & 70 \\
\hline \multirow{3}{*}{$\begin{array}{l}\text { Knowledge of Forensic } \\
\text { Divisions }\end{array}$} & Pearson Correlation & $.264^{n}$ & \multirow[t]{2}{*}{1} & $.368^{2 x}$ & $-281^{x}$ & -171 \\
\hline & Sig. (2-tailed) & .027 & & .002 & .019 & 158 \\
\hline & N & 70 & 70 & 70 & 70 & 70 \\
\hline \multirow{3}{*}{$\begin{array}{l}\text { Challenges and } \\
\text { Importance apply } \\
\text { Forensic Investigation }\end{array}$} & Pearson Correlation & .226 & $.368^{2 x}$ & \multirow[t]{2}{*}{1} & -162 & -.221 \\
\hline & Sig. (2-tailed) & .060 & .002 & & .181 & .065 \\
\hline & N & 70 & 70 & 70 & 70 & 70 \\
\hline \multirow[t]{3}{*}{ Designation } & Pearson Correlation & -187 & $-281^{x}$ & -.162 & 1 & $.550^{2 \pi}$ \\
\hline & Sig. (2-tailed) & .120 & .019 & 181 & & .000 \\
\hline & N & 70 & 70 & 70 & 70 & 70 \\
\hline \multirow[t]{3}{*}{ Year of experience } & Pearson Correlation & -160 & -171 & -.221 & $.550^{\mathrm{min}}$ & 1 \\
\hline & Sig. (2-tailed) & .185 & .158 & .065 & .000 & \\
\hline & N & 70 & 70 & 70 & 70 & 70 \\
\hline
\end{tabular}

Figure 6. Correlation matrix of the variables used in this study

\subsubsection{Knowledge of Forensic Divisions}

From the correlation Matrix a strong positive correlation exist between the designation and knowledge of various forensic divisions ( $\mathrm{r}=0.281$; $\mathrm{p} \leq 0.1$ level) is observed. This indicates that the need for forensic intervention in criminal investigations was mainly limited to the designation of the police officers. 


\subsubsection{Challenges and Importance of forensic interventions}

It can be the seen from the correlation matrix, there is a strong positive correlation $(\mathrm{r}=.162 ; \mathrm{p} \leq .01)$ among the designation of police officers and their challenges faced while using forensic services Moreover without forensic investigation many cases are not proven scientifically and lead to acquittal. This correlation matrix highlights that the knowledge of forensic investigation is must for all police officers in criminal investigation process.

\section{Conclusion}

A survey of police officers working in the Gamo zone was done to determine the views and needs of the forensic science. Majority of the study respondents $(<50 \%)$ were not aware of the use of forensic services in their criminal investigation practice. It was obvious that the investigative capabilities of forensic science are being realized by officers working in higher hierarchy level of police department such as commissioners and inspectors, whereas the first responders like constables and Sub-inspectors have limited forensic literacy. There exists a poor communication between key actors in the criminal justice system and financial resources not directed at the front end of the forensic process. The need for the additional training for law enforcement on the use of forensic science to develop investigative leads is critical. This study emphasizes the need for immediate attention on managing the forensic illiteracy among police officers, mainly on fingerprint analysis, criminal investigation methods and cybercrime.

\section{Acknowledgement}

The authors gratefully acknowledge the police department of Gamo region, SNNPR, Arba Minch for their willingness and support to participate in this survey. We would like to thank all the police officers who participated in the survey. We gratefully acknowledge the academic support of the respective heads and deans of Department of Chemistry and School of Law, Arba Minch University.

\section{References}

[1]. Caldwell, R.G. (1965). Criminology 2nd edition: pp 317. New York .Ronald Press. Retrieved from https://www.researchgate.net/ Retrieved on January 15, 2020.

[2]. Naicker, K. (2017). The recruitment and Management of Agents in Undercover drug Trafficking criminal Investigations (Citied Dowling, J.L. 1979). Magister Technologies thesis, University of South Africa. Retrieved from .unisa.ac.za/ Retrieved on 11 February 2020.
[3]. Horgan, J.J. (1979). Criminal Investigation 2nd edition New York:mc Graw-Hill. Retrieved form www.iletsbeiforumjournal.com Retrieved on December 15, 2020.

[4]. Ward R.H. (1975). Introduction to Criminal Investigation. Massachusetts AddisonWesley.

[5]. UNODC, (2006). Policing Forensic services and infrastructure: Criminal Justice Assessment Toolkit. United Nations Publications.

[6]. United Nations Office on Drugs and Crime. (2009). Laboratory and Scientific Section,. Crime scene and physical evidence awareness for non-forensic personnel. United Nations Publications.

[7]. Lambert, E.G., Hogan, N.L., Nerbonne, T., Barton, S.M., Watson, P.L., Buss, J. and Lambert, J., (2007). Differences in forensic science views and needs of law enforcement: a survey of Michigan law enforcement agencies. Police Practice and Research, 8(5), pp.415430.

[8]. Smith, L.L. and Bull, R., (2014). Exploring the disclosure of forensic evidence in police interviews with suspects. Journal of Police and Criminal Psychology, 29(2), pp.81-86.

[9]. Ethiopian Federal police commission. proclamation No,313/2003. Federal Negarit Gazeta of the federal democratic republic of Ethiopia.

[10]. Criminal Procedure Code of Ethiopia (1961). Art 9-1.

[11]. Shiferaw T.A (2010). Evaluating the Application of Human Rights Principles in Crime Investigation in Ethiopia (A Case Study of The Addis Ababa City Police). Magister Technologies, University of South Africa.

[12]. Mulugeta Ayele. Ethiopia to acquire knowhow for crime investigation. Academic Vice President, Ethiopian police university Interview at Arba Minch University workshop on Forensic-Toxicology. 